\title{
Pharmacologic Control of a Humanized Gene Therapy System Implanted into Nude Mice
}

\author{
Shannon R. Magari, Victor M. Rivera, John D. Iuliucci, Michael Gilman, and Franklin Cerasoli, Jr. \\ ARIAD Gene Therapeutics, Cambridge, Massachusetts 02139
}

\begin{abstract}
Systemic delivery of specific therapeutic proteins by a parenteral route of administration is a recognized practice in the management of several gene defects and acquired diseases. As an alternative to repetitive parenteral administration, gene therapy may provide a novel means for systemic delivery of therapeutic proteins while improving patient compliance and therapeutic efficacy. However, for gene therapy to be an efficacious and safe approach to the clinical management of such diseases, gene expression must be tightly regulated. These investigations demonstrate precise in vivo control of protein expression from cells that are engineered to secrete human growth hormone (hGH) in response to stimulation by rapamycin. The cells were implanted intramuscularly into nu/nu mice and stimulated by intravenous or oral administration of rapamycin. In vivo experiments demonstrate that the activity and pharmacokinetics of rapamycin determine the level of serum hGH that result from the engineered cells. In addition, responsiveness of the cells to rapamycin, number of cells implanted, hGH expression kinetics, and the pharmacokinetics of hGH itself, also influence the circulating levels of hGH after rapamycin stimulation. Controlled manipulation of several of these parameters, either independently or in combination, allows for precise regulation of circulating hGH concentration in vivo. (J. Clin. Invest. 1997. 100:2865-2872.) Key words: rapamycin • human growth hormone $\bullet$ transcription factor $\bullet$ dimerizer
\end{abstract}

\section{Introduction}

Therapeutic proteins, such as cytokines, soluble receptors, and antibodies are employed as effective treatments for several genetic and acquired diseases - often for the lifetime of the patient. However, the efficacy of protein therapy may be compromised for several reasons. First, systemic application of therapeutic proteins is challenging since oral administration of proteins is ineffective and intramuscular or subcutaneous injections may pose compliance problems related to the comfort of the patient. Second, a vast protein concentration gradient may occur in blood, between protein administrations, which

Address correspondence to Franklin Cerasoli, Jr., Ph.D., ARIAD Pharmaceuticals, Inc., 26 Landsdowne St., Cambridge, MA 02139. Phone: 617-494-0400; FAX: 617-494-8144; E-mail: cerasoli@ariad.com Received for publication 9 May 1997 and accepted in revised form 24 September 1997.

J. Clin. Invest.

(C) The American Society for Clinical Investigation, Inc. 0021-9738/97/12/2865/08 \$2.00

Volume 100, Number 11, December 1997, 2865-2872

http://www.jci.org may render the protein useful for only a limited period of time as the concentration passes through a therapeutic window. Finally, in some diseases, such as insulin-dependent diabetes mellitus, the patient is expected to make modestly complicated alterations in dosing, based on self-monitoring. Therefore, while therapeutically necessary, current methods for systemic administration of proteins are sub-optimal.

Gene therapy, in which therapeutic proteins are produced within the patient, may address the above challenges while providing equal or increased therapeutic value. However, gene therapy becomes clinically applicable only if it possesses properties associated with conventional pharmaceutical therapy. The therapy must: (a) be efficacious yet uncomplicated for the patient; $(b)$ be easily managed yet precise, titratable, and controllable by the physician or patient; and $(c)$ produce a therapeutic protein that is dose responsive and easily controlled within a defined therapeutic window.

The last two points are particularly significant since the need for therapeutic proteins may not always exist, may be cyclic, or may be dependent on the patient's daily activities. Unphysiologic, constitutive production, typical of current gene therapy strategies, could lead to several deleterious consequences; including inappropriate downregulation of effector systems, cellular toxicity, and aberrant physiology $(1,2)$. Therefore, pharmacologic regulation of therapeutic protein production is required in most applications but not achieved by conventional gene therapy.

A newly described gene regulation system potentially provides for efficient and safe systemic delivery of expressed therapeutic proteins through the activity of a low molecular weight compound (Fig. 1; reference 3). In this system, gene constructs encode three basic components: $(a)$ a transcriptional activation domain from the $\mathrm{COOH}$-terminal region of the NFkB p65 protein, fused to hFRB, the rapamycin binding domain of hFRAP (4); (b) a chimeric DNA binding domain termed ZFHD1 (5), fused to three copies of hFKBP (6), which also binds rapamycin - at a different portion of the molecule; and (c) a target gene that produces therapeutic protein (human growth hormone $[\mathrm{hGH}]^{1}$ in this prototypic system), under the control of DNA binding sites for ZFHD1. Rapamycin mediates the assembly of fully functional transcription factors, by virtue of the hFRB and hFKBP domains present in the transcription factor fusion proteins. The fusion protein complex initiates transcription, translation, and subsequent secretion of hGH. This system exhibits undetectable background hGH production and rapamycin-dependent production to very high levels (3). The major advantages of this system are: (a) reduced risk of immunologic recognition and elimination from the host $(7,8)$ by the use of entirely human gene components; (b) activation of the system by the presence of a regulating compound $(9,10)$; and $(c)$ modularity of system components

1. Abbreviation used in this paper: $\mathrm{hGH}$, human growth hormone. 

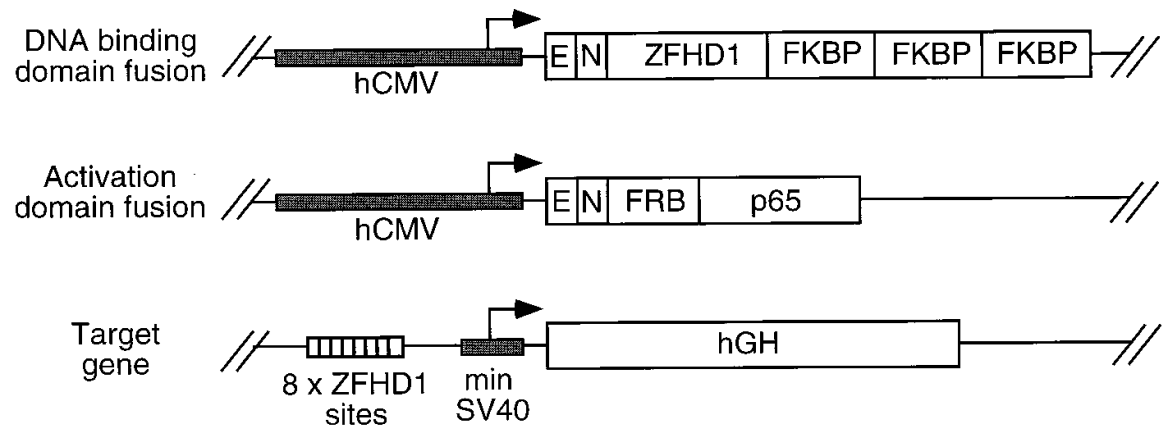

B

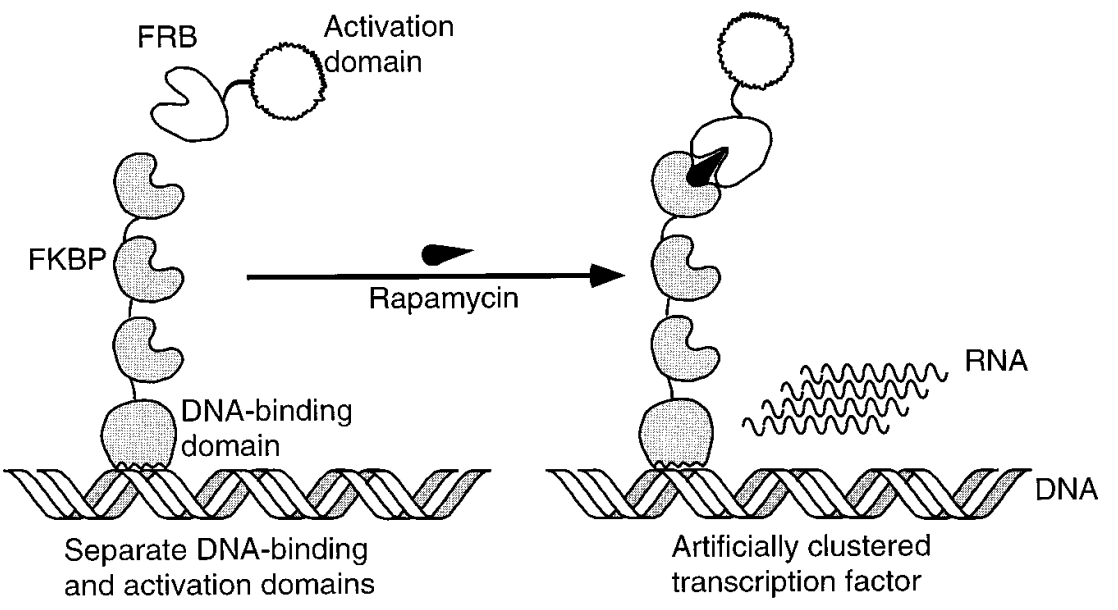

Figure 1. Schematic of the regulated gene therapy system. (A) Schematic diagram of plasmids encoding the reporter gene and transcription factor fusions. The DNA binding domain fusion consists of a DNA binding domain, termed ZFHD1, fused to three copies of hFKBP. The activation domain fusion consists of the transcriptional activation domain from the $\mathrm{COOH}$-terminal region of the $\mathrm{NF}_{\kappa} \mathrm{B}$ p 65 protein fused to hFRB. Both fusion proteins are produced under the control of the human cytomegalovirus promoter $(h C M V)$ immediate early promoter and enhancer. An epitope tag $(E)$ and the SV40 T antigen nuclear localization sequence $(N)$ are included at the amino-terminal. The hGH reporter gene consists of a minimal SV40 promoter ( $\min S V 40$ ) and eight tandemly reiterated ZFHD1 binding sites. (B) Schematic for rapamycin-dependent protein production. The association of the activation and DNA binding domain fusions occurs only in the presence of rapamycin which, through different portions of the molecule, binds to both hFKBP and hFRB. Rapamycin-mediated association of the domains results in a fully functional transcription factor that binds to and activates expression of a target gene containing binding sites for ZFHD1. that allows for broad applicability to many diseases by changing the therapeutic gene (3).

The purpose of these investigations is to demonstrate precise in vivo pharmacologic regulation of therapeutic protein production. The gene constructs, described above, were stably transfected into cells derived from a human fibrosarcoma. Transfected cells were implanted intramuscularly into $\mathrm{nu} / \mathrm{nu}$ mice that were subsequently administered rapamycin. Circulating $\mathrm{hGH}$ concentrations were dependent on the protein production characteristics of the transfected cells, the in vivo characteristics of the secreted protein, and the pharmacokinetic/pharmacodynamic profile of rapamycin. These data suggest that regulated gene therapy may be an efficacious and safe means by which to provide systemic delivery of therapeutic proteins with good compliance.

\section{Methods}

Plasmid construction. All plasmids were constructed as described previously (3). pCGNN-ZFHD1-3hFKBP and the retroviral vector SMTN-ZFHD1-3hFKBP express the ZFHD1 DNA binding domain (5) fused to three copies of hFKBP. pCGNN-1hFRB-p65 expresses the minimal FRB fragment of human FRAP (4) fused to activation domain sequences from the human NFkB p65 subunit (11). The ZHWTx8-
SV-hGH and ZHWTx12-CMV-hGH reporter genes contain 8 or 12 ZFHD1 binding sites and a minimal SV40 or CMV promoter upstream of the hGH gene.

Cellular transfection and culture. HT1080 cells (ATCC CCL-1211; American Type Culture Collection, Rockville, MD), derived from a human fibrosarcoma, were grown in MEM supplemented with nonessential amino acids and 10\% FBS. The stable cell line HT26-1 was generated by sequential transfection or infection of HT1080 cells with SMTN-ZFHD1-3hFKBP, pCGNN-1hFRB-p65, and ZHWT $\times 8$ SV-hGH as described (3). To generate transiently transfected cells, $10 \mu \mathrm{g}$ of ZHWT $\times 12-\mathrm{CMV}$-hGH, $1 \mu \mathrm{g}$ of pCGNN-ZFHD1-3hFKBP, $2 \mu \mathrm{g}$ of pCGNN-1hFRB-p65, and $7 \mu \mathrm{g}$ of pUC118 were introduced into HT1080 cells $\left(2 \times 10^{6}\right.$ per 100 -mm dish $)$ by calcium phosphate precipitation.

For analysis, cells were plated in 24-well dishes $\left(1 \times 10^{5}\right.$ cells per well) and $1 \mathrm{ml}$ medium containing $10 \mathrm{nM}$ rapamycin added. After 18 and $21 \mathrm{~h}$, medium was removed and hGH levels assayed (Nichols Diagnostic, San Clemente, CA). The assay had a lower sensitivity limit of $0.5 \mathrm{ng} / \mathrm{ml}$.

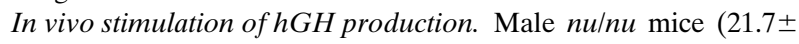
$0.3 \mathrm{~g}$ ) were obtained from Charles River Laboratories (Wilmington, MA), housed under sterile conditions in microisolator cages, and allowed to acclimate for $5 \mathrm{~d}$ before experimentation. They were allowed free access to sterile food and sterile water throughout the entire experiment (unless otherwise specified).

Mice were administered stably transfected HT26-1 or transiently 
transfected HT1080 cells. Two million transfected cells (unless otherwise noted), suspended in $100 \mu \mathrm{lBS} / 0.1 \% \mathrm{BSA} / 0.1 \%$ glucose buffer, were administered into four intramuscular sites $(\sim 25 \mu \mathrm{l}$ per site) on the haunches and flanks of the animals. Some control mice received no transfected cells but did receive injections of cell suspension buffer.

Mice received either intravenous or oral rapamycin that was obtained as a fermentation product of Streptomyces hygroscopicus and extraction from the biomass as described (3). For administration by either route, rapamycin was dissolved in $N, N$-dimethylacetamide to make stock solutions of specific concentrations. Specific volumes of each stock solution were diluted with an equal volume of a mixture comprised of $90 \%$ polyethylene glycol (average molecular mass of 400 ) and $10 \%$ polyoxyethylene sorbitan monooleate. The concentrations of the diluted rapamycin were sufficient to allow for dosing on a $\mathrm{mg} / \mathrm{kg}$ basis in an intravenous injection volume of $2.0 \mathrm{ml} / \mathrm{kg}$ or a gavage volume of $4.0 \mathrm{ml} / \mathrm{kg}$. Some control mice, bearing no transfected cells, received rapamycin. In addition, some control mice, bearing transfected cells, received only the rapamycin vehicle. At various times after rapamycin administration, the mice were killed (unless otherwise noted) via $\mathrm{CO}_{2}$ asphyxiation and were immediately exsanguinated. Blood samples were allowed to clot for $24 \mathrm{~h}$, at $4^{\circ} \mathrm{C}$, and sera were collected following centrifugation at $1,000 \mathrm{~g}$ for $15 \mathrm{~min}$.

Circulating serum hGH was measured by the Boehringer Mannheim nonisotopic sandwich ELISA (Cat No. 1585 878; Boehringer Mannheim Biochemicals, Indianapolis, IN). The assay had a lower detection limit of $12.5 \mathrm{pg} / \mathrm{ml}$ and a dynamic range that extended to 0.4 $\mathrm{ng} / \mathrm{ml}$. Recommended assay instructions were carried out after dilution of samples and standards in stock mouse serum (Sigma Chemical Co., St. Louis, MO). The antibody reagents demonstrate no crossreactivity with endogenous, murine $\mathrm{hGH}$ in diluent sera or native samples (S.R. Magari and F. Cerasoli, unpublished observations; reference 12)

\section{Results}

The hGH producing activity of engineered HT26-1 cells in vitro was dependent on the presence of two transcription factor fusion proteins and rapamycin, the low molecular mass compound with which the fusion proteins interact (3). In the absence of rapamycin, these cells produce no detectable hGH. In the presence of rapamycin, the cells produced $\sim 8.7 \times 10^{-4}$ ng hGH per cell per hour, in vitro. Therefore, HT26-1 cells exhibit rapamycin-dependent hGH secretion with undetectable background and very high induction.

Rapamycin controlled the production of hGH from HT26-1 cells implanted into the skeletal muscle of $n u / n u$ mice. Rapamycin, administered orally, increased circulating hGH concentrations in the serum of mice bearing $2 \times 10^{6}$ cells, in a dosedependent manner (Fig. 2). The lowest stimulating dose was $3.0 \mathrm{mg} / \mathrm{kg}$ and maximum levels were produced by $30.0 \mathrm{mg} / \mathrm{kg}$. For comparison, an intravenous rapamycin dose of $0.1 \mathrm{mg} / \mathrm{kg}$ was the lowest stimulating dose and $10.0 \mathrm{mg} / \mathrm{kg}$ was the lowest dose that produced maximum hGH concentrations (3). Maximum circulating hGH concentrations were similar after either route of administration. The $\mathrm{ED}_{50}$ derived from the intravenous administration $(1.38 \pm 0.14 \mathrm{mg} / \mathrm{kg})$ was $15 \%$ of that derived from the oral administration $(9.18 \pm 0.64 \mathrm{mg} / \mathrm{kg})$. Circulating hGH concentrations in control animals receiving HT26-1 cells and no rapamycin, or rapamycin $(10 \mathrm{mg} / \mathrm{kg}$, i.v. $)$ and no cells, were at or below the detection limit of the hGH assay $(12.5 \mathrm{pg} / \mathrm{ml})$.

Circulating hGH was elevated for prolonged periods after stimulation of implanted HT26-1 cells by a single intravenous or oral dose of $5.0 \mathrm{mg} / \mathrm{kg}$ of rapamycin (Fig. 3). Peak hGH lev-

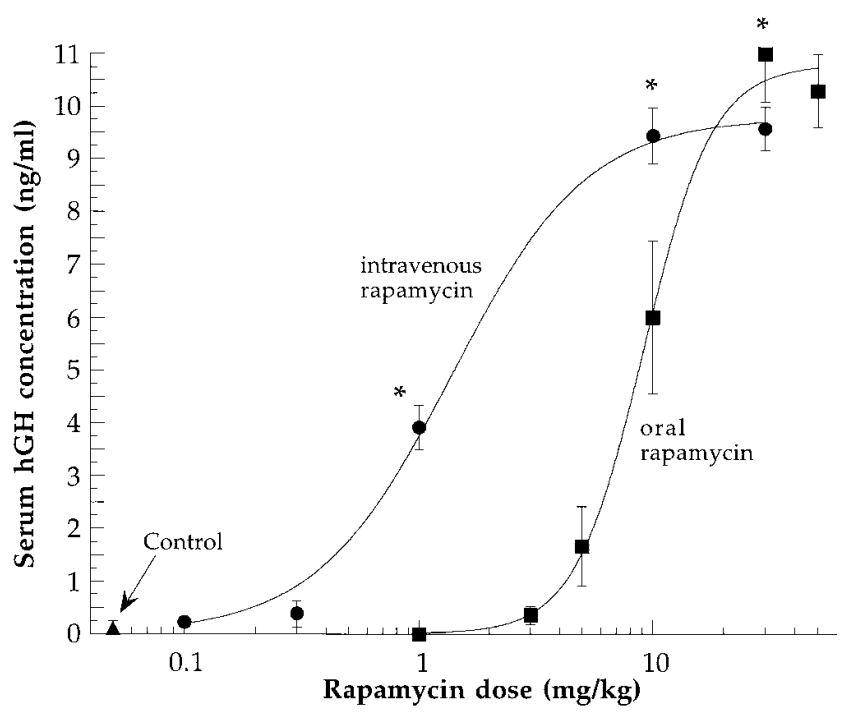

Figure 2. Serum hGH concentration in $n u / n u$ mice receiving HT26-1 cells and various doses of rapamycin. Mice received $2 \times 10^{6}$ HT26- 1 cells, a stably transfected clonal cell line derived from HT1080 cells, in four intramuscular sites. Approximately $30 \mathrm{~min}$ after implantation, the mice received oral doses of rapamycin. The mice were killed $17 \mathrm{~h}$ after rapamycin administration and blood was collected for hGH determination in serum. Circulating serum hGH concentrations dose dependently increased in response to rapamycin. Values after intravenous administration of rapamycin are included for comparison (adapted with permission, reference 3 ). The $\mathrm{ED}_{50}$ of the oral rapamycin administration was $9.18 \pm 0.64 \mathrm{mg} / \mathrm{kg}$ and that of the intravenous administration was $1.38 \pm 0.14 \mathrm{mg} / \mathrm{kg}$. Peak hGH levels were independent of the rapamycin administration route. Values are mean \pm one SEM, $n=$ at least 5 per point. *Represents statistical significance from each lower rapamycin dose; $P<0.05$, one-way ANOVA and Tukey-Kramer multiple comparison testing.

els were $23.40 \pm 0.78$ and $4.09 \pm 1.98 \mathrm{ng} / \mathrm{ml}$, resulting from intravenous and oral administrations, respectively. These levels occurred at one day after either route of administration. $3 \mathrm{~d}$ after intravenous and oral administration, hGH levels began to decrease with a half-life of $1 \mathrm{~d}$. The time course of circulating hGH was such that circulating levels could still be detected in the final blood collection; i.e., 8 and $12 \mathrm{~d}$ after oral and intravenous administrations, respectively. Prolonged circulating levels of $\mathrm{hGH}$ were unexpected in view of the short hGH half-life, which is minutes in mice (S.R. Magari and F. Cerasoli, unpublished observation; reference 12), and the 4.5-h apparent elimination half-life of rapamycin, measured in mice to support these studies (S.R. Magari and F. Cerasoli, unpublished observation).

To better understand the prolonged in vivo hGH kinetics, the in vitro kinetics of hGH secretion were assessed. HT26-1 cells were exposed in vitro to a single 24-h pulse of rapamycin and the amount of hGH secreted during the first and subsequent 24-h intervals was measured. hGH secretion peaked 24 $48 \mathrm{~h}$ after addition of rapamycin; which was similar to the in vivo hGH secretion kinetics (Fig. 4). In addition, beginning in the third 24-h interval, the hGH levels declined with an average half-life of $1.5 \mathrm{~d}$ (calculated from the third through the eighth 24-h interval).

While the experiments above were designed to demon- 


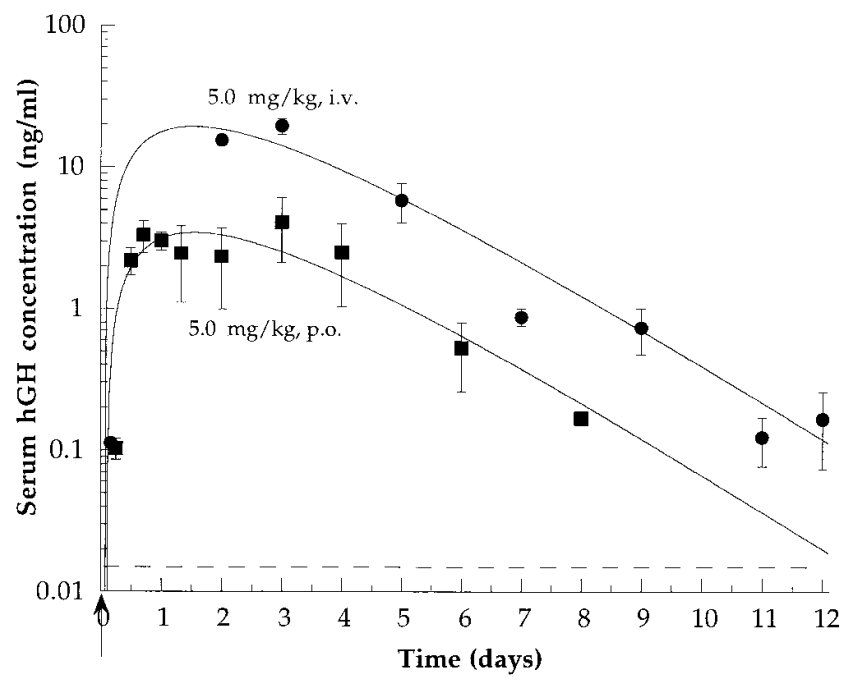

Figure 3. Time course of serum hGH levels after a single rapamycin administration. $n u / n u$ mice received $2 \times 10^{6}$ HT26-1 cells intramuscularly. Approximately $30 \mathrm{~min}$ later, they received a $5-\mathrm{mg} / \mathrm{kg}$ dose of rapamycin either by the intravenous or by the oral route. The mice were killed at the indicated times and blood was collected for hGH determination in serum. A one compartment model with first-order absorption and elimination was used to successfully model the hGH kinetics (31). The lag time between rapamycin administration and estimated first measurable hGH concentration was $\sim 3 \mathrm{~h}$. Circulating $\mathrm{hGH}$ concentrations peaked by one day after administration and decayed, beginning on day 3 , with a half-life of $1 \mathrm{~d}$. The time course of $\mathrm{hGH}$ production, after either route of rapamycin administration, was identical. Values are mean \pm one SEM, $n=$ at least 5 per point. The arrow represents rapamycin administration and the dotted line indicates the lower detection limit of the hGH assay.

strate that circulating hGH levels were dependent on the route and dose of rapamycin administration, subsequent experiments were designed to demonstrate that the characteristics of the implanted cells also determined circulating hGH levels. Implantation of various numbers of transfected cells regulated the serum hGH concentration resulting from a single dose of rapamycin $(5.0 \mathrm{mg} / \mathrm{kg}$, i.v.; Fig. 5). The lowest number of cells administered $\left(2 \times 10^{4}\right.$ cells per animal $)$ produced an average circulating hGH level below the lower detection limit of the assay; 6 animals produced no hGH while one animal produced $0.015 \mathrm{ng} / \mathrm{ml}$ of $\mathrm{hGH}$. The maximum circulating hGH level $(89.01 \pm 6.80 \mathrm{ng} / \mathrm{ml})$ was achieved with the maximum number of cells administered $\left(2 \times 10^{7}\right.$ cells per animal $)$. Control animals, receiving $2 \times 10^{6}$ cells per animal and no rapamycin or rapamycin and no cells, produced no detectable serum hGH.

Implantation of transfected cells, possessing different in vitro production rates, produced different circulating hGH levels in vivo after stimulation (Fig. 6). HT1080 cells, engineered to produce hGH in response to rapamycin by transient transfection of the necessary gene constructs, produced $1.10 \times 10^{-4} \mathrm{ng}$ hGH per cell per hour when stimulated with $10 \mathrm{nM}$ rapamycin in vitro. The rate of $\mathrm{hGH}$ production from stably transfected HT26-1 cells was 7.9-fold greater than from transiently transfected HT1080 cells when stimulated by the same in vitro conditions. This difference in production rates, between the two cell lines, was paralleled in vivo. Serum hGH from mice implanted with HT1080 cells and stimulated with $10 \mathrm{mg} / \mathrm{kg}$ rapa-

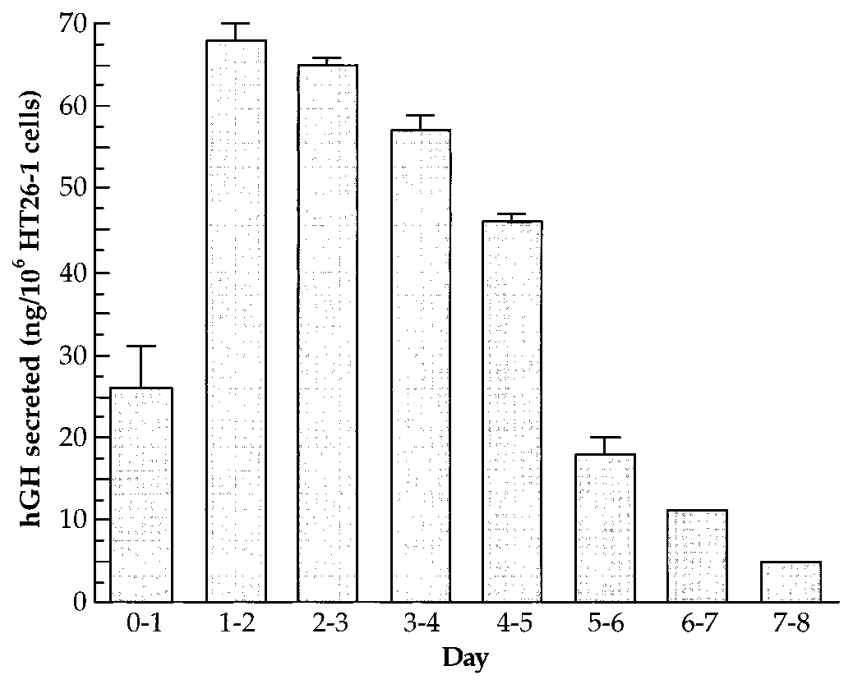

Figure 4. In vitro secretion kinetics of hGH in response to a single 24-h pulse of rapamycin. HT26-1 cells were plated in 6-well dishes $\left(2 \times 10^{5}\right.$ cells per well) with $4.0 \mathrm{ml}$ medium containing $10 \mathrm{nM}$ rapamycin (demonstrated previously to be a maximally stimulating concentration; reference 3 ). The medium was removed after $24 \mathrm{~h}$ and assayed for $\mathrm{hGH}$. Fresh medium was added for an additional $24 \mathrm{~h}$ after which it was removed and assayed. This was repeated six additional times. Rapamycin stimulated hGH secretion from HT26-1 cells within the first $24 \mathrm{~h}$ of culture. hGH secretion continued in the absence of rapamycin and peaked in the second $24 \mathrm{~h}$ period. Secretion remained elevated in the third interval and began to decrease thereafter. The secretion rate decreased with a half-life of $1.5 \mathrm{~d}$. Values are mean \pm one SEM. $n=3$ per point.

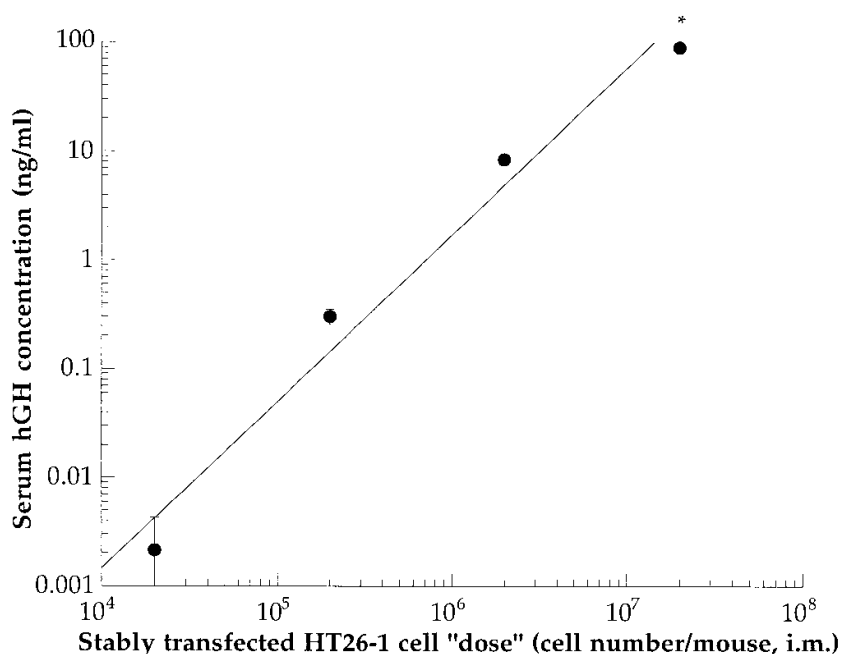

Figure 5. Serum hGH in $n u / n u$ mice administered various numbers of HT26-1 cells and a single intravenous rapamycin dose. Increasing numbers of HT26-1 cells were implanted intramuscularly. Approximately 30 min later, a single dose of rapamycin $(5.0 \mathrm{mg} / \mathrm{kg})$ was administered intravenously. Circulating hGH increased with increasing implanted cell number. The maximum response was observed with $2 \times 10^{7}$ cells per animal which produced $89.0 \pm 6.8 \mathrm{ng} / \mathrm{ml}$ circulating $\mathrm{hGH}$. No plateau in the hGH response was observed. Control mice, receiving $2 \times 10^{6}$ cells and no drug, did not produce detectable levels of hGH. Mean \pm one SEM, $n=7$ per point. *Represents statistical significance from each lower cell number; $P<0.05$, one-way ANOVA and Tukey-Kramer multiple comparison testing. 


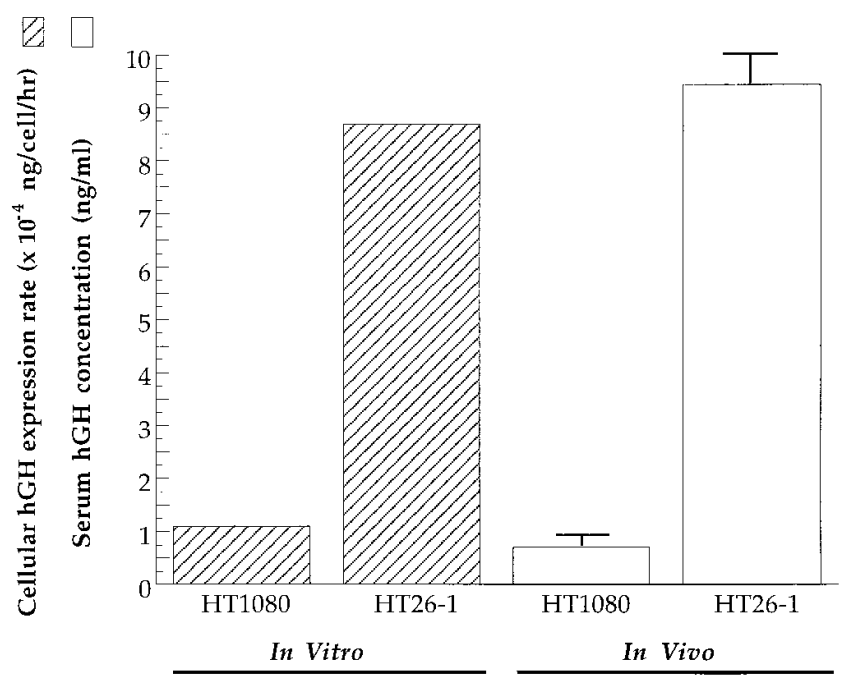

Figure 6. In vitro and in vivo secretion of hGH from transfected cell possessing different hGH production rates. For in vitro analysis of hGH production rates, HT1080 and HT26-1 cells were plated in 24well dishes $\left(1 \times 10^{5}\right.$ cells per well $)$ with $1.0 \mathrm{ml}$ medium containing $10 \mathrm{nM}$ rapamycin (demonstrated previously to be a maximally stimulating concentration; reference 3 ). Medium was removed at 18 and $21 \mathrm{~h}$ and assayed for hGH in order to determine the hourly production rate per cell. HT26-1 cells $\left(2 \times 10^{6}\right)$ were implanted intramuscularly into $n u / n u$ mice. Additionally, HT1080 cells were implanted into separate mice. Approximately 30 min later, all mice received intravenous rapamycin $(10 \mathrm{mg} / \mathrm{kg}$,). Blood was collected $17 \mathrm{~h}$ after rapamycin administration and the serum hGH was measured. The in vitro hGH production rate from HT1080 cells was 8.1-fold lower than the in vitro production rate from HT26-1 cells. The differences in the in vitro production rates between the two cell lines were borne out in vivo. Mice implanted with HT26-1 cells had serum hGH levels that were 13 -fold higher than in mice implanted with HT1080 cells.

mycin, i.v., was $0.71 \pm 0.07 \mathrm{ng} / \mathrm{ml}$. This circulating serum hGH concentration was 13 -fold higher in animals implanted with HT26-1 cells.

Precise in vivo manipulation of circulating hGH was tested by stimulation of HT26-1 cells with multiple administrations of oral rapamycin at various doses and dosing regimens. Serum $\mathrm{hGH}$ levels were predicted a priori at each sampling time (see below) with consideration of: (a) 15\% oral bioavailability of rapamycin; $(b)$ circulating hGH levels based on rapamycin dose; $(c)$ implanted cell number; $(d)$ protein expression rate of the implanted cells; and (e) kinetics of circulating hGH after a single rapamycin dose (i.e., one day to reach peak concentrations, two days at peak concentrations, and an apparent halflife of elimination of one day). Mice were implanted with HT26-1 cells $\left(2 \times 10^{6}\right.$, i.m. $)$. A rapamycin dose of $5.0 \mathrm{mg} / \mathrm{kg}$ was administered on days $0,2,6$, and 10 . Mice then received 30 $\mathrm{mg} / \mathrm{kg}$ of rapamycin on days $17,18,23$, and 27 . Blood was sampled on all dosing days before administration and at various times after administration.

The predicted and observed serum hGH levels are shown in Fig. 7. Rapamycin $(5.0 \mathrm{mg} / \mathrm{kg})$ produced circulating $\mathrm{hGH}$ concentrations that could be accurately predicted. The hGH levels were increased by rapamycin doses on days 0 and 2 . hGH levels were then decreased in a controlled and predicted fashion (from $1.51 \pm 0.46$ on day 3 to $0.77 \pm 0.40$ on day 10 ) by separating the second and third doses by $5 \mathrm{~d}$ (one day to peak, two days on a plateau, and two half-lives) rather than $4 \mathrm{~d}$ (one day to peak, two days on a plateau, and one half-life) which would be predicted sufficient to maintain circulating hGH at a pre-determined concentration. The elimination of circulating $\mathrm{hGH}$, after the last $5.0 \mathrm{mg} / \mathrm{kg}$ dose, was predicted to occur on day 13, as determined previously (Fig. 3), with a half-life of one day. The onset of elimination occurred on day 11 with an apparent elimination half-life of $1.3 \pm 0.2 \mathrm{~d}$ (calculated from hGH concentrations measured on days 11, 14, 15, and 17).

Rapamycin doses of $30.0 \mathrm{mg} / \mathrm{kg}$ on days 17 and 18 sequentially increased circulating hGH levels that ultimately peaked on day 19. Additional administrations of $30.0 \mathrm{mg} / \mathrm{kg}$ rapamycin on days 23 and 27 produced the expected fluctuations in the circulating hGH levels. Again, the elimination onset after the last dose of $30.0 \mathrm{mg} / \mathrm{kg}$ of rapamycin was different from predicted; however, the apparent elimination half-life was $0.96 \pm 0.06$ days (calculated from hGH concentrations measured on days $31,33,35$, and 37 ).

Comparison of the predicted results and observed data confirm that control of circulating hGH release was possible through well-defined rapamycin dosing regimens (Table I). All observed values were statistically similar to the paired predicted values, with the exception of the complete curve for the

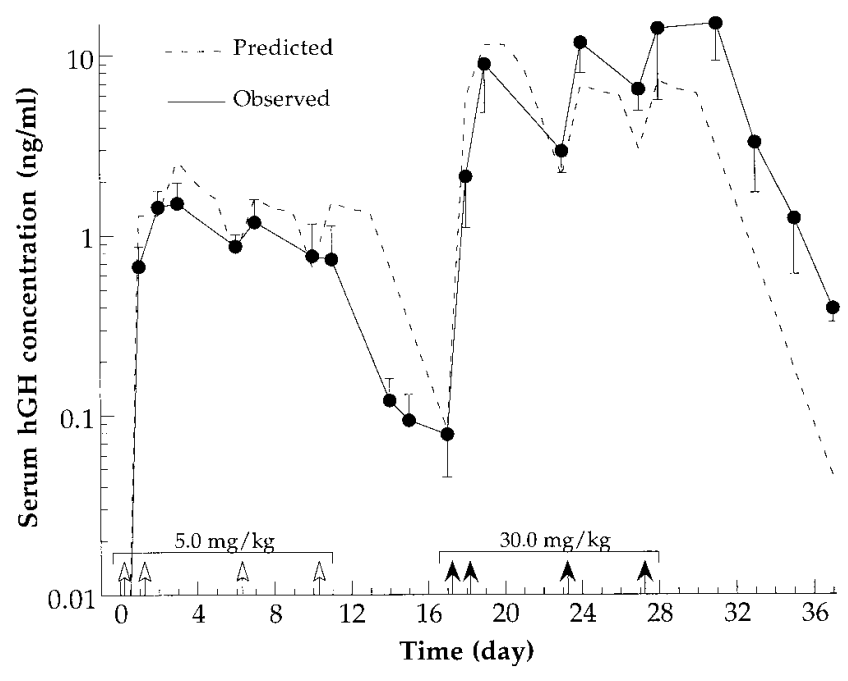

Figure 7. Circulating hGH concentrations from $n u / n u$ mice treated repeatedly with oral rapamycin. Mice received $2 \times 10^{6}$ HT26- 1 cells intramuscularly. Approximately $30 \mathrm{~min}$ later, the first of four oral rapamycin doses $(5.0 \mathrm{mg} / \mathrm{kg}$, open arrows) was given. Blood samples were collected by orbital bleeding or cardiac puncture following $\mathrm{CO}_{2}$, anesthesia and the resulting serum was assayed for hGH. The mice then received $30.0 \mathrm{mg} / \mathrm{kg}$ rapamycin doses on days $17,18,23$, and 27 (filled arrows) and blood sample collection was performed as above. Filled circles on the solid line represent actual hGH levels obtained from measurement in the serum of mice. Values are mean \pm one SEM, $n=$ at least 4 per point. The dashed line represents hGH serum concentrations predicted a priori to be achieved by the rapamycin dosing regimens. This was based on circulating hGH concentrations obtained from rapamycin doses of 5.0 and $30.0 \mathrm{mg} / \mathrm{kg}$ (Fig. 2) as well as by the time course of circulating hGH levels after a single rapamycin dose (Fig. 3) that possesses the following characteristics: $(a)$ an hGH plateau $24 \mathrm{~h}$ following rapamycin; (b) maintenance of the plateau for an additional two days; and $(c)$ an apparent elimination halflife of $1 \mathrm{~d}$. 
Table I. Comparison of Predicted and Observed Serum hGH Concentrations After Multiple Administrations of Rapamycin

\begin{tabular}{clllll}
\hline & & \multicolumn{3}{c}{ Serum hGH concentration $(\mathrm{ng} / \mathrm{ml})$} \\
\cline { 3 - 6 } & & \multicolumn{2}{c}{$5.0 \mathrm{mg} / \mathrm{kg}$} & \multicolumn{2}{c}{$30 \mathrm{mg} / \mathrm{kg}$} \\
\hline Complete & Predicted & $1.09 \pm 0.23^{\S}$ & $P<0.05^{\|}$ & $4.07 \pm 1.18$ & $\mathrm{NS} \|$ \\
curve* $^{*}$ & Observed & $0.75 \pm 0.17$ & & $6.64 \pm 1.74$ & \\
Plateau $^{\ddagger}$ & Predicted & $1.41 \pm 0.28$ & $\mathrm{NS} \|$ & $6.17 \pm 1.69$ & $\mathrm{NS}$ \\
& Observed & $1.09 \pm 0.14$ & & $8.87 \pm 1.96$ & $P<0.05^{\|}$
\end{tabular}

* Complete curve values were obtained from days 1, 2, 3, 6, 7, 10, 11, 14, 15 , and 17 for the $5.0 \mathrm{mg} / \mathrm{kg}$ dosing regimen, and days $18,19,23,24,27$, $28,31,33$, and 35 for the $30.0 \mathrm{mg} / \mathrm{kg}$ dosing regimen. Predicted values were calculated based on the serum hGH levels, based on the oral rapamycin dose response (Fig. 2) as well as a $3 \mathrm{~d}$ plateau, and the $1 \mathrm{~d}$ apparent elimination half-life (Fig. 3). ${ }^{\ddagger}$ Plateau values were obtained from days $2,3,6,7,10$, and 11 for the $5.0 \mathrm{~kg} / \mathrm{kg}$ dosing regimen, and days 19 , $23,24,27$, and 28 for the $30.0 \mathrm{mg} / \mathrm{kg}$ dosing regimen. Predicted values were as described above. ${ }^{8}$ Values are mean \pm one SE of the mean. "Statistical comparison to Observed. Paired $t$ test. "Statistical comparison to Observed, $5.0 \mathrm{mg} / \mathrm{kg}$. Paired $t$ test.

$5.0 \mathrm{mg} / \mathrm{kg}$ dose. The earlier occurrence of the onset of elimination (day 11 rather than day 13 as predicted; Fig. 7) produced the statistical significance since the predicted and observed plateau hGH levels for the $5.0 \mathrm{mg} / \mathrm{kg}$ doses were statistically similar. The observed plateau during the $30.0 \mathrm{mg} / \mathrm{kg}$ dose regimen was statistically greater than that observed during the 5.0 $\mathrm{mg} / \mathrm{kg}$ dose regimen.

Rapamycin was well tolerated. All mice were healthyeven in the multiple dose experiments. There was no body weight loss or other clinical symptoms. Overt renal toxicity was not observed. Hematologic measurements were not made; however, the animals in the multiple dose experiment were expected to be immunosuppressed because of the dose of rapamycin used and the frequency of administration (13-17).

\section{Discussion}

These studies demonstrate in vivo control of circulating hGH synthesized from engineered cells that are responsive to rapamycin. Circulating hGH levels are dependent on the protein production characteristics of the transfected cells, the in vivo characteristics of the secreted protein, and the pharmacokinetic/pharmacodynamic profile of rapamycin. The regulation afforded by this gene therapy system precisely controls circulating protein levels in vivo.

The ability of rapamycin to stimulate $\mathrm{hGH}$ production in HT26-1 cells is governed by the responsiveness of the cells to rapamycin which is in turn governed by the affinity of the molecule for its receptors, hFKBP and hFRB. Rapamycin elicits $\mathrm{hGH}$ production dose dependently, after either intravenous (3) or oral administration, with wide dynamic range (Fig. 2). Implanted cells produce no detectable hGH in the absence of rapamycin suggesting complete dependence of gene expression on the drug. Therefore, this regulated gene therapy system allows for precise protein production and secretion, at discrete rapamycin doses to achieve circulating hGH concentrations that are necessary for human therapy (18-20).
The absorption, distribution, and potentially other pharmacokinetic properties of rapamycin also determine in vivo hGH production. For example, in pharmacokinetic studies performed to support the current experiments (S.R. Magari and F. Cerasoli, unpublished observations), the absolute oral bioavailability of rapamycin was measured as $15 \%$ which corroborates previous animal and clinical studies (21-24). This degree of oral bioavailability and resultant circulating and/or tissue rapamycin concentrations, to which the HT26-1 cells are exposed, explains why intravenous rapamycin yields an $\mathrm{ED}_{50}$ that is $16.3 \%$ of the oral $\mathrm{ED}_{50}(\sim 1.3$ and $8.0 \mathrm{mg} / \mathrm{kg}$, respectively; Fig. 2). The relationship is further elucidated by peak levels of circulating hGH after oral administration of identical rapamycin doses $(5.0 \mathrm{mg} / \mathrm{kg})$. The peak hGH concentration after oral rapamycin is $17.4 \%$ of that achieved with intravenous administration $(4.09 \pm 1.98 \mathrm{ng} / \mathrm{ml}$, and $23.39 \pm 0.78 \mathrm{ng} / \mathrm{ml}$, respectively; Fig. 3). Distribution of rapamycin throughout the body, with respect to the anatomic implantation site of HT26-1 cell, is another pharmacologic parameter that may affect circulating hGH concentrations. Circulating hGH concentrations from HT26-1 cells implanted intramuscularly or intraperitoneally (S.R. Magari and F. Cerasoli, unpublished observations) are similar after rapamycin administration $(5.0 \mathrm{mg} / \mathrm{kg}$, p.o.); suggesting that rapamycin concentrations in these two anatomic sites are similar. Therefore, absorption, distribution, and the circulating and/or tissue concentrations of rapamycin that result, following any given dose by any route, contribute to the production of circulating hGH from HT26-1 cells in vivo.

Surprisingly, several lines of evidence indicate that rapamycin's pharmacokinetic profile is not the sole determinant of circulating hGH kinetics. First, there is discrepancy between rapamycin absorption kinetics and time of peak hGH concentration. The maximum rapamycin concentration, after oral administration, occurs within 20 min of administration (S.R. Magari and F. Cerasoli, unpublished observations); however, circulating hGH peaks one day after both intravenous and oral rapamycin administration. This lag time (Fig. 3) is most likely due to the combined rate constants for intracellular processes including activation of transcription by rapamycin, accumulation of mRNA, and protein production and secretion. Second, the apparent elimination half-life of circulating hGH (1 d) is much longer than the apparent elimination half-life of rapamycin (4.5 h in mice; S.R. Magari and F. Cerasoli, unpublished observations). Theoretically, the two rates should be identical and equal to the apparent elimination rate of rapamycin since the half-life of hGH, after its intravenous administration, is mere minutes (S.R. Magari and F. Cerasoli, unpublished observations; reference 12). Combined, these observations suggest that processes unrelated to rapamycin pharmacokinetics contribute to the kinetics of circulating hGH concentration.

The prolonged in vivo kinetics of circulating hGH apparently result from the inherent protein production kinetics of the HT26-1 cells. This was demonstrated by in vitro experiments in which the prolonged profile of hGH production was remarkably similar to the in vivo kinetics (Fig. 4). Therefore, the inherent kinetics of protein production from the $\mathrm{hGH}$ gene, which are governed by mRNA accumulation and slow degradation (reported to be $30 \mathrm{~h}$ for the bovine hGH gene, reference 25), are the primary determinants of serum hGH concentrations in vivo. This is not the case for genes with shorter inherent protein production kinetics. For example, the in vitro production of secreted alkaline phosphatase, a reporter pro- 
tein used in a manner analogous to $\mathrm{hGH}$, is significantly shorter than hGH (V.M. Rivera, unpublished observations). Indeed, rapamycin stimulation of engineered cells with an hGH gene modified by the addition of elements (26) that reduce the half-life of its mRNA, results in transient in vitro secretion of hGH and lower peak concentrations (V.M. Rivera, unpublished observations). Therefore, the in vivo and in vitro kinetics of protein production, in part, reflect expression properties of the particular gene, which can be engineered to produce protein with kinetics more reflective of compound pharmacokinetics.

The number of implanted engineered cells and their protein production rates also contribute to the circulating hGH concentrations. Cell numbers between $2 \times 10^{4}$ and $2 \times 10^{5}$ are the threshold for detection of circulating hGH production while twenty million implanted cells increase the circulating hGH to extraordinarily high levels_approaching $100 \mathrm{ng} / \mathrm{ml}$. No plateau is apparent in the cell dose-response curve (Fig. 5) suggesting that the $5.0 \mathrm{mg} / \mathrm{kg}$ dose of rapamycin is sufficient to stimulate cells in excess of $2 \times 10^{7}$ in vivo. Very high circulating $\mathrm{hGH}$ concentrations $(>100 \mathrm{ng} / \mathrm{ml})$ may be achieved if higher rapamycin doses are used along with the highest cell dose; however, this has not been tested. The in vitro protein production rate of the HT26-1 cells is $8.7 \times 10^{-4} \mathrm{ng}$ per cell per hour and these cells produce $9.5-10.0 \mathrm{ng} / \mathrm{ml}$ circulating $\mathrm{hGH}$ when stimulated with an intravenous rapamycin dose of $10 \mathrm{mg} /$ kg (Fig. 6). In contrast, HT1080 cells (the transiently transfected parent line of HT26-1), with an in vitro production rate of $1.1 \times 10^{-4} \mathrm{ng} \mathrm{hGH}$ per cell per hour in vitro, produce $\sim 1.0$ $\mathrm{ng} / \mathrm{ml}$ circulating hGH in vivo, with the same rapamycin dose. Therefore, the 8- to 9-fold difference in hGH production observed in vitro directly translates to the same-fold difference in in vivo production. The data presented here indicate that the number of implanted cells and their associated protein production rate regulates and provides a wide dynamic range of circulating concentration of secreted protein in vivo. It is important to note that HT26-1, used in these experiments, is a clonal cell line; therefore, hGH expression is likely to be homogenous across all cells in the population. Under some circumstances, such as cellular transduction with gene therapy vectors in vivo, individual cell expression rates may vary because of differences in expression levels of individual genes. Evaluation of cellular heterogeneity and the resulting range of protein expression, under such circumstances, is an important area for future investigation in the use of regulated gene therapy.

The exquisite control of this gene therapy system over circulating hGH levels is best exemplified by the multiple rapamycin administration experiment (Fig. 7) which precisely manipulates circulating hGH levels through the use of various doses and dosing regimens of oral rapamycin. Circulating hGH concentrations are accurately maintained at levels predicted a priori. For example, increasing the rapamycin doses to $30.0 \mathrm{mg} / \mathrm{kg}$ on days 17 and 18 increases circulating hGH to a level that is 6.2-fold higher on day 19 than the level on day 2, after the 5.0 $\mathrm{mg} / \mathrm{kg}$ dose. This result is predicted by the 6.6 -fold increase obtained from the oral dose response of 5 and $30 \mathrm{mg} / \mathrm{kg}$ ( $1.67 \pm 0.75$ and $11.00 \pm 0.90 \mathrm{ng} / \mathrm{ml}$, respectively; Fig. 2$)$. The observed plateau during the $30 \mathrm{mg} / \mathrm{kg}$ dose regimen is statistically greater than that observed during the $5 \mathrm{mg} / \mathrm{kg}$ dose regimen (Table I) suggesting that these two dose levels maintain circulating hGH concentrations commensurate with their respective abilities to stimulate hGH production. The onset of elimi- nation, after the last $5.0 \mathrm{mg} / \mathrm{kg}$ dose and the last $30.0 \mathrm{mg} / \mathrm{kg}$ dose, both differed from their respective predicted onsets. In the $5.0 \mathrm{mg} / \mathrm{kg}$ case, the difference may be an experimental artifact since blood samples were not collected on day 12 or 13 when the hGH concentrations are expected to be high. The difference after the $30.0 \mathrm{mg} / \mathrm{kg}$ is less interpretable and suggests that the transition periods between different dosing regimens may be more difficult to predict. The rates of hGH elimination after the 5.0 and $30.0 \mathrm{mg} / \mathrm{kg}$ dose regimens (half-lives of $1.3 \pm 0.2$ days and $0.96 \pm 0.09$ days, respectively) are as predicted (one day; Fig. 3). These data demonstrate that this regulated gene therapy system achieves precise regulation of hGH levels which can be maintained for more than a month after cell implantation into the host.

Two potential limitations of the system require attention before its clinical application. First, the native immunosuppressive activity of rapamycin $(17,27-29)$ must be ablated for chronic use. Nonimmunosuppressive rapamycin analogues may be synthesized by modification of rapamycin that abrogate its ability to bind endogenous host hFKBP and/or hFRAP. High affinity binding of the analogue may then be regained by placing amino acid substitutions at strategic positions within the proteins, engineered into the gene construct, so that they interact only with the appropriately modified rapamycin analogue. Such re-engineering of a drug-protein interface has been successfully achieved with the cyclosporin-cyclophilin complex (30). The second potential limitation is the presence of small junctional peptide sequences within the fusion proteins, which may prompt immunologic recognition of the engineered cells. The immunologic significance of these sequences requires characterization, despite the fact that they are comprised of only two amino acids, that the remaining portions of the fusion proteins are completely human, and that the fusion proteins are expressed intracellularly at relatively low levels. Like rapamycin analogues, immunostimulatory junction peptides could be replaced by nonimmunogenic variants.

In summary, these experiments demonstrate that pharmacologic regulation of gene therapy can precisely control circulating protein levels in vivo from implanted, stably transfected cells that are designed to secrete $\mathrm{hGH}$ in response to stimulation by rapamycin. The potency, efficacy, and pharmacokinetics of rapamycin contribute to the circulating concentration of $\mathrm{hGH}$ that is released from the HT26-1 cells. In addition, several cellular characteristics, including sensitivity of the cells to rapamycin, number of cells implanted, hGH production kinetics, as well as the pharmacokinetics of hGH itself, also contribute to the circulating levels of hGH after rapamycin stimulation. Controlled manipulation of any parameter, either independently or in combination, allows for precise titration of circulating hGH concentration. Such a regulated gene therapy system allows for the safe and prolonged delivery of therapeutic proteins by virtue of both implantation of specifically engineered cells and oral administration of therapeutic compound to which the cells are responsive.

\section{Acknowledgments}

The authors wish to express their thanks to Chris Stearns for assistance in the preparation of this manuscript; Heather Salzburg, Karin Stebbins, and Susan Wood for their technical assistance in the in vivo work; Nancy Courage for her technical assistance in the maintenance of the cell lines; Terence Keenan and Tom Phillips for the production 
and purification of rapamycin; Tim Clackson, Sridar Nateson, and Roy Pollock for construction of the transcription factor fusion proteins; David Dalgarno, Bonnie Marmor, and Ruth Yuan for their assistance in the analytical chemistry and pharmacokinetic experiments that support this work; Dennis Holt for insights into the progress of this work; and David Berstein for his critical review of this manuscript.

\section{References}

1. Isgaard, J., L. Carlsson, O. Isaksson, and J. Jansson. 1988. Pulsatile intravenous growth hormone $(\mathrm{GH})$ infusion to hypophysectomized rats increases insulin-like growth factor I messenger ribonucleic acid in skeletal tissues more effectively than continuous GH infusion. Endocrinology. 123:2605-2610.

2. Wolf, E., E. Kahnt, J. Ehrlein, W. Hermanns, G. Brem, and R. Wanke. 1993. Effects of long-term elevated serum levels of growth hormone on life expectancy of mice: lessons learned from transgenic animal models. Mech. Ageing Dev. 68:71-87.

3. Rivera, V., T. Clackson, S. Natesan, R. Pollock, J. Amara, T. Keenan, S. Magari, T. Phillips, N. Courage, F. Cerasoli, et al. 1996. A humanized system for pharmacologic control of gene expression. Nat. Med. 2:1028-1032.

4. Chen, J., X. Zheng, E. Brown, and S. Schreiber. 1995. Identification of an $11 \mathrm{kDa}$ hFKBP12-rapamycin binding domain within the 289-kDa hFKBP-rapamycin-associated protein and characterization of a critical serine residue. Proc. Natl. Acad. Sci. USA. 92:4947-4951.

5. Pomerantz, J., P. Sharp, and C. Pabo. 1995. Structure-based design of transcription factors. Science. 267:93-96.

6. Standaert, R., A. Galat, G. Verdine, and S. Schreiber. 1990. Molecular cloning and overexpression of the human FK506-binding protein hFKBP. $\mathrm{Na}$ ture. 346:671-674.

7. Riddell, S. 1996. T-cell mediated rejection of gene-modified HIV-specific cytotoxic T lymphocytes in HIV-infected patients. Nat. Med. 2:216-223.

8. Wang, Y., B.W. O'Malley, Jr., S. Tsai, and B.W. O'Malley. 1994. A regulatory system for use in gene transfer. Proc. Natl. Acad. Sci. USA. 91:8180-8184.

9. Bohl, D., N. Naffakh, and J. Heard. 1997. Long-term control of erythropoietin secretion by doxycycline in mice transplanted with engineered primary myoblasts. Nat. Med. 3:299-305.

10. Dhawan, J., T. Rando, S. Elson, H. Bujard, and H. Blau. 1995. Tetracycline-regulated gene expression following direct gene transfer into mouse skeletal muscle. Som. Cell Mol. Genet. 21:233-240.

11. Schmitz, M., and P. Baeuerle. 1991. The p65 subunit is responsible for the strong transcription activating potential of NF-kappa B. EMBO (Eur. Mol. Biol. Organ.) J. 10:3805-3817.

12. Heartlein, M., V. Roman, J. Jtang, J. Sellers, A. Zuliani, D. Treco, and R. Selden. 1994. Long-term production and delivery of human growth hormone. Proc. Natl. Acad. Sci. USA. 91:10967-10971.

13. Kahan, B., J. Chang, and S. Sehgal. 1991. Preclinical evaluation of a new potent immunosuppressive agent, rapamycin. Transplantation (Baltimore). 52: $185-191$

14. Kay, J., L. Kromwel, S. Doe, and M. Denyer. 1991. Inhibition of T and B lymphocyte proliferation by rapamycin. Immunology. 72:544-549.

15. Sehgal, S., K. Molnar-Kimbar, T. Ocain, and B. Weichman. 1994. Rapamycin: a novel immunosuppressive macrolide. Med. Res. Rev. 14:1-22.

16. Stepkowski, S., H. Chen, P. Daloze, and B. Kahan. 1991. Rapamycin, a potent immunosuppressive drug for vascularized heart, kidney, and small bowel transplantation in the rat. Transplantation (Baltimore). 51:22-26.

17. Abraham, R.T., and G.J. Wiederrecht. 1996. Immunopharmacology of rapamycin. Ann. Rev. Immunol. 14:483-510.

18. Hindmarsh, P., and C. Brook. 1996. Final height of short normal children treated with growth hormone. Lancet (N. Am. Ed.). 348:13-16.

19. Amato, G., G. Izzo, G. La Montagna, and A. Bellastella. 1996. Low dose recombinant human growth hormone normalizes bone metabolism and cortical bone density and improves trabecular bone density in growth hormone deficient adults without causing adverse effects. Clin. Endocrinol. 45:27-32.

20. Oscarsson, J., G. Lindstedt, P. Lundberg, and S. Eden. 1996. Continuous subcutaneous infusion of low dose growth hormone decreases serum sex-hormone binding globulin and testosterone concentrations in moderately obese middle-aged men. Clin. Endocrinol. 44:23-29.

21. Yatscoff, R. 1996. Pharmacokinetics of rapamycin. Transplant. Proc. 28: 970-973.

22. Baker, H., S. Sehgal, and C. Vezna. 1978. Rapamycin (AY-22,989), a new antifungal antibiotic. III. In vitro and in vivo evaluation. J. Antibiot. (Tokyo). 31:539-545.

23. Granger, D., J. Cromwell, S. Chen, J. Goswitz, D. Morrow, F. Beierle, S. Sehgal, D. Canafax, and A. Matas. 1995. Prolongation of renal allograft survival in a large animal model by oral rapamycin monotherapy. Transplantation (Baltimore). 59:183-186.

24. Dias, V., and R. Yatscoff. 1994. Investigation of rapamycin transport and uptake across absorptive human intestinal cell monolayers. Clin. Biochem. 27:31-36.

25. Helms, S., and F. Rottman. 1990. Characterization of an inducible promoter system to investigate decay of stable mRNA molecules. Nucleic Acids Res. 18:255-259.

26. Shyu, A.-B., J. Belasco, and M. Greenberg. 1991. Two distinct destabilizing elements in the c-fos message trigger deadenylation as a first step in rapid mRNA decay. Genes Dev. 5:221-231.

27. Carlson, R.P., and S.N. Sehgal. 1996. Effect of rapamycin in animal models of arthritis and other autoimmune diseases. In Principles of Drug Development in Transplantation and Autoimmunity. R.G. Landes Co., Austin TX. 303-308.

28. Chen, H.F., S.J. Qi, D.S. Xu, J.P. Wu, and P. Daloze. 1996. The immunosuppressive effect of rapamycin on mouse small bowel transplantation Transplantation (Baltimore). 61:523-526.

29. Christians, U., and K.F. Sewing. 1996. Pharmacokinetics, metabolism and therapeutic drug monitoring of the macrolide immunosuppressants tacrolimus (FK506) and sirolimus (rapamycin). In Principles of Drug Development in Transplantation and Autoimmunity. R.G. Landes Co., Austin, TX. 483-505.

30. Belshaw, P., J. Schoepfer, K. Liu, K. Morrison, and S. Schreiber. 1995 Rational design of orthogonal receptor-ligand combinations. Angew. Chem. Int. Ed. Eng. 34:2129-2132.

31. Gibaldi, M., and D. Perrier. 1982. Pharmacokinetics. Marcel Dekker, Inc., New York. pp. 145-198. 